\title{
Activity of Piperaceae extracts and fractions in the control of Phytomonas serpens
}

\author{
Neriani de Souza Cancini ${ }^{1}$ (D) Jesieli Beraldo-Borrazzo ${ }^{2}$ (D) Jéssica Lima de Menezes $^{3}$ (D) \\ Diógenes Aparício Garcia Cortez ${ }^{\dagger}$ Rodrigo Hinojosa Valdez ${ }^{5}$ (i) Francielle Pelegrin Garcia ${ }^{6}$ (i) \\ Sueli Fumie Yamada-Ogatta ${ }^{7}$ (i) Benedito Prado Dias Filho ${ }^{6}$ Tânia Ueda-Nakamura $^{6}$ (i) \\ Celso Vataru Nakamura ${ }^{6}$ Benício Alves de Abreu Filho ${ }^{6^{*}}$ (i)
}

${ }^{1}$ Departamento de Ciências Biológicas, Universidade Estadual de Maringá (UEM), Maringá, PR, Brasil.

${ }^{2}$ Departamento de Biotecnologia, Genética e Biologia Celular, Universidade Estadual de Maringá (UEM), Maringá, PR, Brasil.

${ }^{3}$ Programa de Pós-graduação em Ciência de Alimentos, Universidade Estadual de Maringá (UEM), Maringá, PR, Brasil.

${ }^{4}$ Departamento de Farmácia, Universidade Estadual de Maringá (UEM), Maringá, PR, Brasil. In memorian.

${ }^{5}$ Instituto Federal do Paraná (IFPR), Cascavel, PR, Brasil.

${ }^{6}$ Departamento de Ciências Básicas da Saúde, Universidade Estadual de Maringá (UEM), 87020-900, Maringá, PR, Brasil. E-mail: baafilho@uem.br.

"Corresponding author.

${ }^{7}$ Departamento de Microbiologia, Universidade Estadual de Londrina (UEL), Londrina, PR, Brasil.

ABSTRACT: Protozoa of the genus Phytomonas are harmful parasites to several agricultural crops of economic importance. Due to their recognized biological activity, crude extracts of Piper aduncum, P. crassinervium, P. hispidum, and P. amalago leaves, were tested using the microdilution plate technique to assess the antiparasitic potential against Phytomonas serpens. Results showed that the ethanolic crude extract of $P$. crassinervium and P. amalago presented the best inhibitory concentration for $50 \%$ of the cells (IC $\left.{ }_{50}\right), 16.5 \mu \mathrm{g} L^{-1}$ in chloroform phase, and $18 \mu \mathrm{g} \mathrm{mL} \mathrm{L}^{-1}$ in aqueous phase, respectively, after $48 \mathrm{~h}$ treatment. Cytotoxicity analyses were performed using the colorimetric method of sulforhodamine-B in LLCMK, mammalian cells. The chloroform phase of P. crassinervium was subjected to the fractionation process, in which the ethyl acetate and dichloromethane fractions obtained better $I_{50}$ values. Scanning electron microscopy (SEM) images showed alterations in the cell membrane of the treated parasites. The data obtained indicate a potential antiparasitic effect of the Piper species analyzed against $P$. serpens, being considered promising candidates for formulations of bioproducts to control the parasite.

Key words: antiparasitic activity, medicinal plants, Piper, Trypanosomatid, Phytomonas.

Atividade de extratos e frações de Piperaceae no controle de Phytomonas serpens

RESUMO: Protozoários do gênero Phytomonas são parasitas prejudiciais a várias culturas agrícolas de importância econômica. Devido a sua atividade biológica reconhecida, extratos brutos de folhas de Piper aduncum, P. crassinervium, P. hispidum e P. amalago, foram testadas pela técnica de microdiluição em placa para avaliar o seu potencial antiparasitário contra Phytomonas serpens. Os resultados mostraram que o extrato bruto etanólico de P. crassinervium e P. amalago apresentaram as melhores concentrações inibitórias para 50\% das células (IC 50 ),

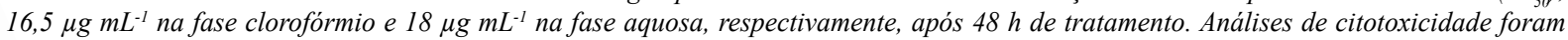
realizadas através do método colorimétrico da sulforodamina- $B$, em células de mamíferos LLCMK2. A fase clorofórmio de P. crassinervium foi submetida ao processo de fracionamento, no qual as frações acetato de etila e diclorometano obtiveram melhores valores de IC $C_{50}$. Imagens de microscopia eletrônica de varredura (MEV) mostraram alterações na membrana celular dos parasitas tratados com fase aquosa de P. amalago. Os dados obtidos indicam potencial efeito antiparasitário das espécies de Piper analisadas contra P. serpens, sendo consideradas candidatas promissoras para formulações de bioprodutos para controle do parasito.

Palavras-chave: atividade antiparasitária, plantas medicinais, Piper, Tripanossomatídeo, Phytomonas.

\section{INTRODUCTION}

Species of the Trypanosomatidae family are pathogenic protozoa that cause various diseases, affecting vertebrate animals, humans, and plants. In humans, these flagellates are etiological agents of Chagas disease (Trypanosoma cruzi) and Leishmaniasis (Leishmania spp.). In plants, Phytomonas is a genus of trypanosomatids, composed of several species recognized as significant pathogens, responsible for 
producing diseases in tropical agricultural crops of great economic interest (MASLOV et al., 2018).

Studies showed that some species of Phytomonas spp. are capable of causing lethal plant diseases, while others cause minor damage, infecting different plant tissues such as dairy ducts, phloem, seeds, flowers, and fruits. Phytomonas are an example of dixenic trypanosomatids, which affect both the invertebrate host and plants as a promastigote (CAMARGO et al., 1999). Transmitted by phytophages, these hemipterous insects are popularly known as bedbugs, and they are responsible for spreading the infection to more than 100 plant species (KAUFER et al., 2017). Among them, important crops such as tomatoes, coffee, cassava, cocoa trees, and palm trees that produce oil and coconut (PORCEL et al., 2014; FROLOV et al., 2019).

For a long time there were doubts about correlating the genus Phytomonas, as being phytopathogen or only endophytic to plant hosts, because its differentiation is complex and it does not produce easily detectable effects on plant growth or yield (ABREU FILHO et al., 2001). Since initial research on the pathogenicity of Phytomonas begun, two main species producing plant diseases have been identified: Phytomonas staheli that causes sudden wilt in coconut trees (Cocos nucifera) and slow wilt in oil palm (Elaeis guineensis). In these cases, leaf wilt leads to root rot. Additionally, Phytomonas leptovasorum causes phloem necrosis in Arabica and Liberica coffee (JASKOWSKA et al., 2015). The species Phytomonas serpens is isolated only in tomato fruit. The fruit infected by the insects Phthia picta and Nezara viridula present yellowish spots that result in nutritional loss and; consequently, lead to commercial impracticability of the product (JANKEVICIUS et al., 1989). Phytomonas serpens is also attributed to the production of auxin, a class of phytohormones that ends up causing interference with the plant metabolism, thus affecting plant development (IENNE et al., 2014). Despite the damage caused to crops, P. serpens is not considered a phytopathogen parasite, since the promastigote form of the parasite remains restricted to the place of infection (OLIVEIRA et al., 2017).

Despite being globally present, such as in African, European, and Asian countries, species of Phytomonas are considered endemic in South America, with a significant number of species in Brazil, which makes them a food security risk for many economies around the world. (DA SILVA et al., 2013). The most significant losses are registered mainly in developing countries, such as Colombia, Brazil, Ecuador and Costa Rica, which concentrate their export economies on tropical crops affected by Phytomonas. Besides, there are no adequate chemical control and treatment against these microorganisms, which requires the felling of the sick plant or the removal of infected plant material (JASKOWSKA et al., 2015).

In this sense, many studies point to plants as a potential source of new phytochemical substances, whose extracts can be used as antimicrobial agents (PEREIRA et al., 2018). The genus Piper has around 2000 species, and it is common in tropical and subtropical regions of the Atlantic Forest (PRANDO et al., 2014). Traditionally, these plants are used by the population of these regions in the treatment of influenza, cough, and rheumatism once they have ethnomedicinal properties. They are popularly known as pepper plants or false jaborandi (LAGO and KATO, 2007).

A complex of natural products is synthesized from the secondary metabolism of Piper, consisting in a mixture of bioactive organic compounds such as phenols, terpenes, esters, alcohols, among others (KUMAR et al., 2018). Several studies recognized these compounds for their biological activity as bactericides and fungicides (COSTA et al., 2016; PASCOLI et al., 2018; FERNANDEZ et al, 2019), antiprotozoans (GARCIA et al., 2013; VILLAMIZAR et al., 2017), antitumoral (LONGATO et al., 2011) and antivirals (BERTOL et al., 2012).

Thus, the objective of this study was to evaluate the antimicrobial activity of the crude extract and fractions of Piper amalago, P. aduncum, $P$. hispidum, and $P$. crassinervium, against $P$. serpens, aiming the use of natural compounds with antiparasitic action.

\section{MATERIALS AND METHODS}

\section{Plant material}

The plant specimens analyzed in this study were identified by Dr. Adriana Lenita Albiero from the State University of Maringá and deposited in its Herbarium. The leaves of (1) Piper amalago L. (HUEM 9885), (2) Piper aduncum L. (HUEM 9651) and (3) Piper hispidum Sw (HUEM 9137), were collected from Dr. Luiz Teixeira Mendes forest reserve in Maringá- Paraná, Brazil (coordinates: $23^{\circ}$ 26 '03.1 'S 5'58'04.7). The leaves of the plant (4) Piper crassinervium H.B. \& K. (HUEM 9884) were collected from Prof. Irenice Silva Medicinal Herbs Garden in the campus of the State University of Maringá (coordinates $23^{\circ} 24^{\prime} 12.0^{\prime \prime} \mathrm{S}, 51^{\circ} 56^{\prime} 22.5^{\prime \prime} \mathrm{W}$ ).

Preparation of crude extract and fractionation

The fresh leaves were dried in air circulation greenhouse (Quimis ${ }^{\odot}$, model Q-31, Diadema-SP, 
Brazil) at $40{ }^{\circ} \mathrm{C}$. Three days later, the material was crushed in a knife grinder (Tecnal Marconi $R^{\odot}$, model TE048, Piracicaba, Brazil) and then powdered. Extracts of Piper species were obtained by the maceration method at room temperature with ethanol: water $(9: 1$, $\mathrm{v} / \mathrm{v})$, resulting in raw extracts. The extracts were filtered and evaporated under vacuum at $40{ }^{\circ} \mathrm{C}$ to obtain an aqueous extract. This freeze-dried aqueous extract was subjected to direct extraction with chloroform (without partition), generating a fraction soluble in chloroform, which was later removed generating the aqueous chloroform extract used in clinical tests (Figure 1).

The extracts were kept in a freezer at approximately $-20{ }^{\circ} \mathrm{C}$. The active chloroform extract of $P$. crassinervium was processed by vacuum adsorption column chromatography on silica gel 60 (70 to 230 mesh) and eluted with hexane, hexane: dichloromethane (50: 50; v/v), dichloromethane, ethyl acetate, and methanol, yielding 5 fractions.

\section{Maintenance of Phytomonas serpens}

Promastigote forms of $P$. serpens $\left(15^{\mathrm{T}}\right.$ strain) were kept in Warren medium (Warren, 1960) $\mathrm{pH} 7.0$, supplemented with $10 \%$ inactivated bovine fetal serum (SFB - Gibco Invitrogen Corporation, New York, USA) at $28^{\circ} \mathrm{C}$.

\section{Antipromastigote activity}

Crude extracts and fractions of Piper species assessed were dissolved in dimethylsulfoxide (DMSO) and Phosphate-bufferid saline (PBS), obtaining a stock solution of $10,000 \mu \mathrm{g} \mathrm{mL} \mathrm{mL}^{-1}$. Subsequently, dilutions were performed in Warren medium to obtain final concentrations of 1000,500 , 100,50 , and $10 \mu \mathrm{g} \mathrm{mL}^{-1}$. In these concentrations, protozoa with $48 \mathrm{~h}$ culture (initial inoculum of $1 \times 10^{6}$ cells $/ \mathrm{mL}$ ) were added. The assays were performed in 24-well microplates, incubated at $28^{\circ} \mathrm{C}$. After 48 $\mathrm{h}$, growth was evaluated by counting the protozoa

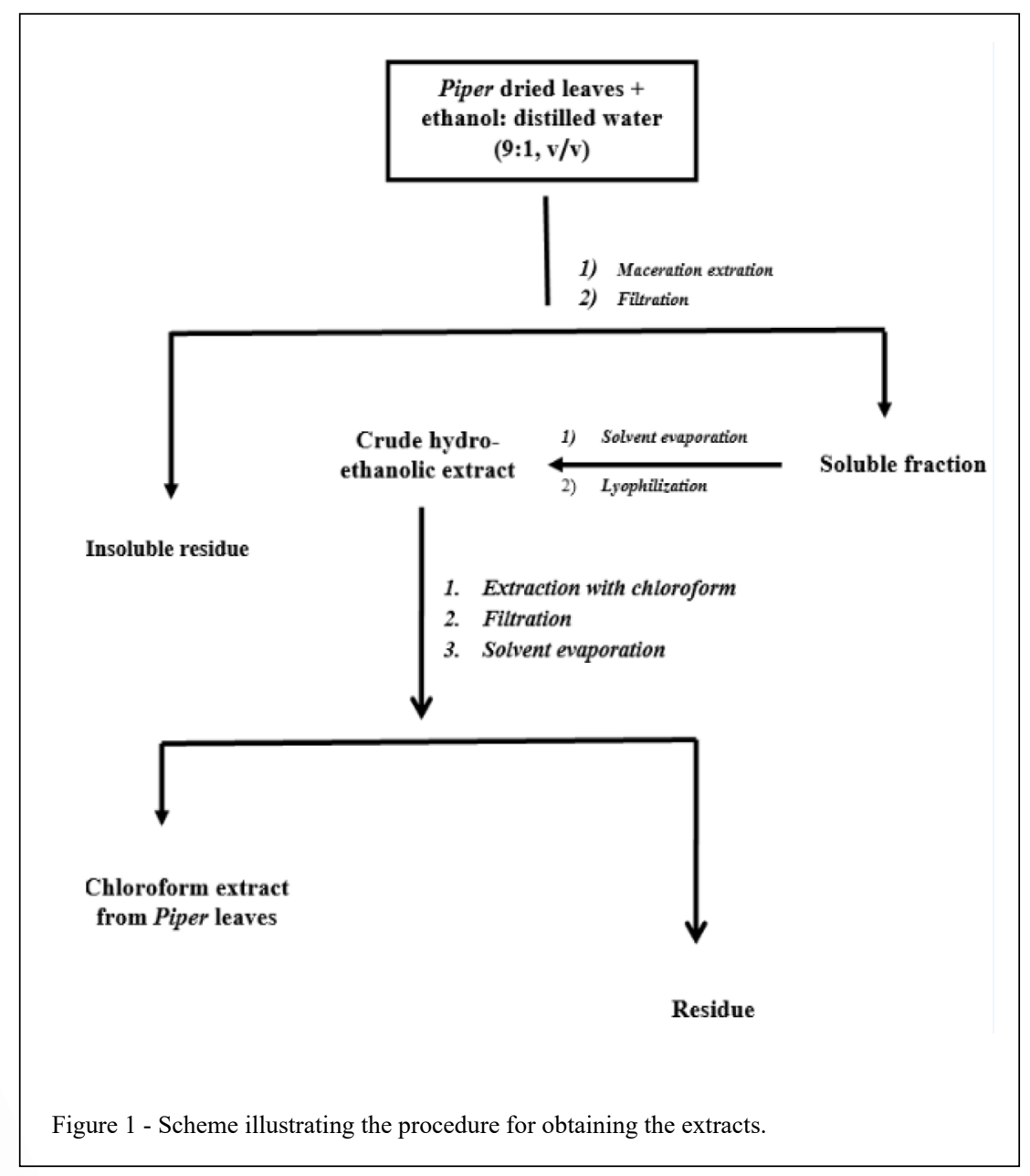

Ciência Rural, v.50, n.10, 2020. 
in the Neubauer chamber. Later, the percentage that inhibited $50 \%$ of protozoa growth was calculated $\left(\mathrm{IC}_{50}\right)$. Protozoa culture with no addition of extracts was used as a negative control.

\section{Cytotoxicity assay}

A suspension of $100 \mu \mathrm{L}$ of $\mathrm{LLCMK}_{2}$ cells (Macaca mulatta kidney epithelial cells) at a concentration of $2.5 \times 10^{5}$ cels $/ \mathrm{mL}$ in DMEM (Dulbecco Modified Eagle Medium-GibcoR $\left.{ }^{\circledR}\right)$ was seeded in 96well plates and incubated at $37{ }^{\circ} \mathrm{C}$ with a $5 \% \mathrm{CO}_{2}$ tension. After $24 \mathrm{~h}$ incubation, $100 \mu \mathrm{L}$ of the various concentrations of crude extract solutions - P. aduncum, P. crassinervium, $P$. hispidum, and P. amalago - were added and incubated for additional $96 \mathrm{~h}$. Cell growth was evaluated by the colorimetric method of sulforodamine B, according to SKEHAN et al. (1990). The reading was performed in an ELISA reader (BioTek FL-600 Microplate Fluorescence Reader) at an optical density of $530 \mathrm{~nm}$ and then the $\mathrm{CC}_{50}$ (cytotoxic concentration for $50 \%$ of cells) was calculated. The results were expressed as the percentage of growth inhibition with regards to the control.

\section{Scanning electron microscopy (SEM)}

Promastigotes $\left(1 \times 10^{6} \quad\right.$ cells $\left./ \mathrm{mL}\right)$ were treated with $18 \mu \mathrm{g} \mathrm{mL}-1$ of $P$. amalago aqueous extract for $48 \mathrm{~h}$ at $28{ }^{\circ} \mathrm{C}$ and then fixed in $2.5 \%$ glutaraldehyde in $0.1 \mathrm{M}$ sodium cacodylate buffer for $1 \mathrm{~h}$. Afterwards, the parasites were adhered to L-lysine coated coverslips and dehydrated in increasing concentrations of ethanol. The samples were dried at a critical $\mathrm{CO}_{2}$ point, gold coated, and observed with a Shimadzu SS-550 scanning electron microscope (Japan) (GARCIA et al., 2013).

\section{Statistical analysis}

All tests were carried out in triplicate, and the data were analyzed through Analysis of Variance (ANOVA). Tukey's test was conducted, and a p-value of $\leq 0,05$ was considered significant compared with the control group. The statistical analysis was performed with the program Graph-Pad Prism 4, USA.

\section{RESULTS AND DISCUSSION}

Among the tools that are most explored to biological control we have the use of plant extracts. Several studies have shown the wide biological activity of plant species that belong to the genus Piper. Recently FERNANDEZ et al. (2019) has reported promising results in vitro of dichloromethane fractions activity of Piper corcovadensis extract (Miq.) against
Mycobacterium tuberculosis. PASCOLI et al. (2018) showed the antibacterial activity of crude extract and fractions of Piper peltatum and Piper marginatum against Alicyclobacillus acidoterrestris. The hexanedichloromethane fraction of $P$. peltatum was the one that provided the best effect.

In our research, we first evaluated antiproliferative activity of hydroalcoholic crude extracts - chloroform phase (Figure 2), and aqueous phase (Figure 3) of $P$. hispidum, $P$. aduncum, $P$. amalago and $P$. crassinervium against promastigote forms of $P$. serpens, after $48 \mathrm{~h}$ incubation. The $\mathrm{IC}_{50}$ values obtained are shown in table 1 . The chloroform phase of $P$. crassinervium demonstrated the best antiproliferative effect against $P$. serpens when compared with the chloroform phase of other Piper species. Among the aqueous phase extracts, $P$. amalago presented the lowest $\mathrm{IC}_{50}$ in $P$. serpens.

Similar results were presented by LOPES et al. (2008) in the assay with isolated compounds of $P$. crassinervium leaves that were evaluated against epimastigote forms of $T$. cruzi. The prenylated hydroquinone exhibited trypanocidal

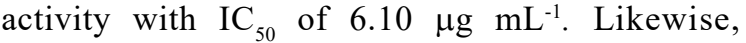
CARRARA et al. (2012) demonstrated the activity against promastigote forms of $L$. amazonensis from $P$. amalago leaf extraction. The extract showed significant antiproliferative activity against promastigotes, with an $\mathrm{IC}_{50}$ of $15 \mu \mathrm{g} \mathrm{mL}^{-1}$.

An essential criterion in the research for active compounds with antiprotozoal activity is their toxicity on mammalian cells. For this purpose, the cytotoxicity of the extracts was evaluated on mammalian cells $\mathrm{LLCMK}_{2}$. After $96 \mathrm{~h}$ treatment, the cytotoxic concentration for $50 \%$ of the cells $\left(\mathrm{CC}_{50}\right)$ was determined using the colorimetric method of sulforhodamine-B. $\mathrm{CC}_{50}$ values are exposed in Table 1. The $\mathrm{CC}_{50}$ obtained in the chloroform phase for all evaluated Piper species showed moderate toxicity, whereas the aqueous extracts showed low toxicity, with $\mathrm{CC}_{50}>850 \mu \mathrm{g} \mathrm{mL}^{-1}$.

Extracts cytotoxicity of Piper species on $\mathrm{LLCMK}_{2}$ mammalian cells was compared with the antiproliferative activity against promastigotes of $P$. serpens, using the selectivity index (SI), the ratio between $\mathrm{CC}_{50}$ for LLCMK 2 cells and $\mathrm{IC}_{50}$ for protozoa. According to table 1, the aqueous fraction of $P$. amalago extract presented the best SI among the Piper species analyzed, which means that it was 47.5 times more toxic to promastigote forms of $P$. serpens than $\mathrm{LLCMK}_{2}$ cells.

Therefore, the best selectivity indexes were presented by $P$. amalago in aqueous phase and by $P$. crassinervium in chloroform phase. Most 


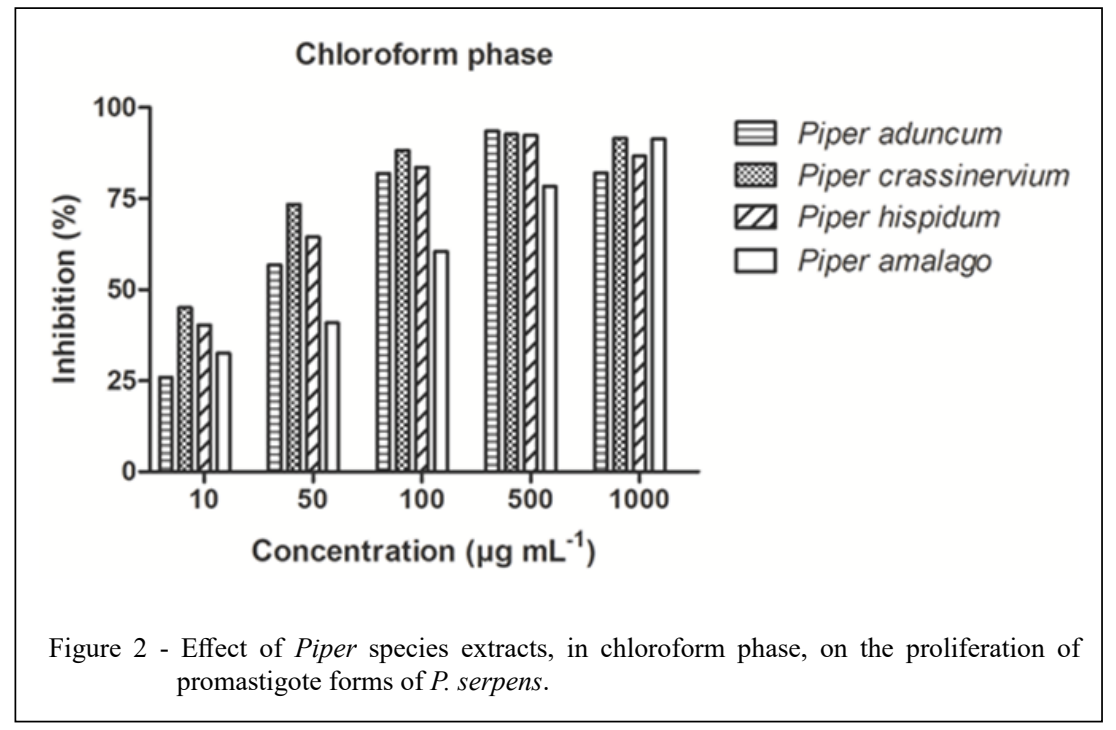

extracts were more toxic to the parasite than to mammalian cells.

In our results, the chloroform phase of $P$. crassinervium and the aqueous phase of $P$. amalago were selected for additional tests once they presented a more significant antiproliferative effect and a better selectivity index. The chloroform phase of $P$. crassinervium was submitted to the fractioning process. According to CARGNIN et al. (2013) and BAPELA et al. (2017) the compounds that present significant antiprotozoal activity are among those capable of being extracted by apolar solvents.

Figure 4 shows the antiproliferative activity of the five fractions obtained from $P$. crassinervium (Hexane fraction, Hexan-Dichloromethane fraction (1:1), Dichloromethane fraction, Ethyl acetate fraction, and Methanol fraction). The most active fractions were dichloromethane and ethyl acetate, both with an $\mathrm{IC}_{50}<10 \mu \mathrm{g} \mathrm{mL}^{-1}$. The methanol fraction showed $\mathrm{IC}_{50}$ of $13 \mu \mathrm{g} \mathrm{mL}^{-1}$ and the hexane, and hexane dichloromethane fractions presented $\mathrm{IC}_{50}$ of 84 and $47 \mu \mathrm{g} \mathrm{mL}^{-1}$, respectively. DMSO at the

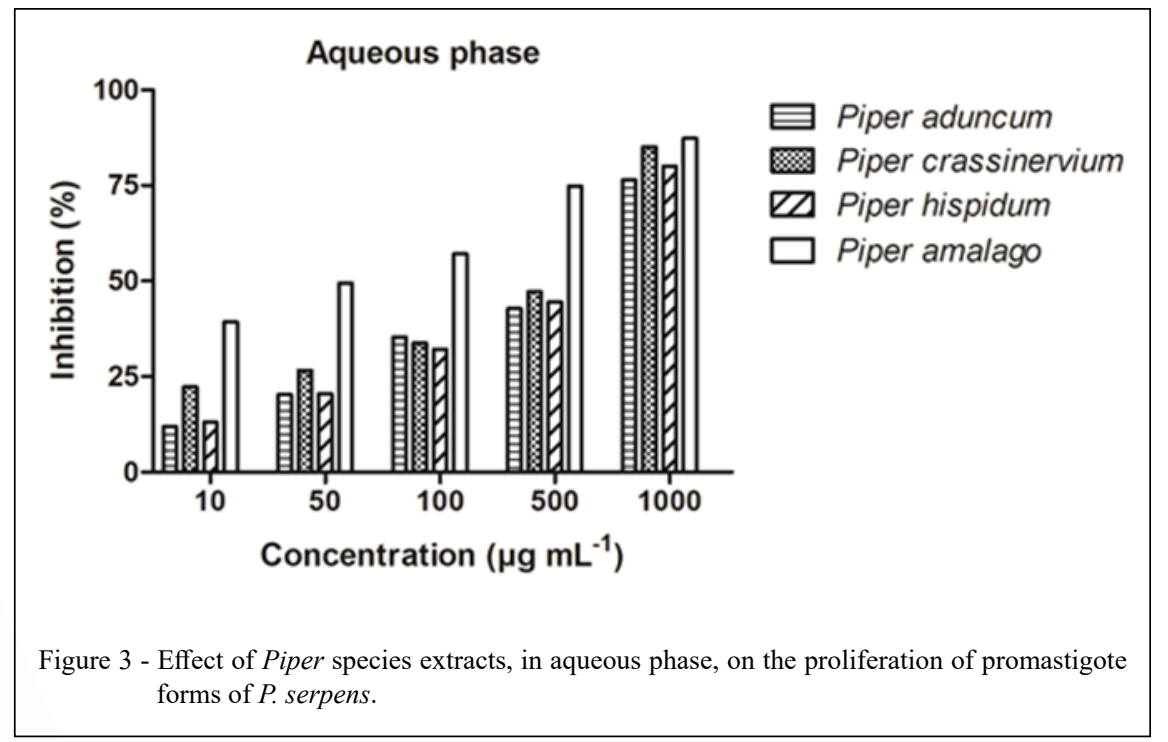

Ciência Rural, v.50, n.10, 2020. 
Table 1 - $\mathrm{IC}_{50}$ values for promastigotes of Phytomonas serpens; cytotoxic effects $\left(\mathrm{CC}_{50}\right)$ for $\mathrm{LLCMK}_{2}$ cells and their respective selectivity indexes (SI).

\begin{tabular}{|c|c|c|c|}
\hline Crude Extracts & $\begin{array}{l}\text { Promastigotes } \\
\mathrm{IC}_{50}\left(\mu \mathrm{g} \mathrm{mL}^{-1}\right)\end{array}$ & $\begin{array}{c}\text { Cytotoxicity } \\
\mathrm{CC}_{50}\left(\mu \mathrm{g} \mathrm{mL}^{-1}\right)\end{array}$ & SI \\
\hline \multicolumn{4}{|c|}{ 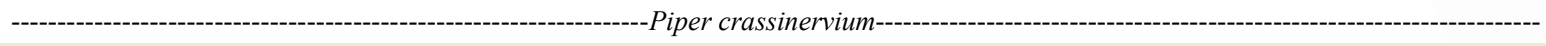 } \\
\hline Chloroform phase & $16.5 \pm 0.7$ & $210.0 \pm 14.0$ & 12.7 \\
\hline Aqueous phase & $557.5 \pm 3.5$ & $>1000 \pm 0$ & $>1.8$ \\
\hline \multicolumn{4}{|c|}{------------------------------- } \\
\hline Chloroform phase & $22.0 \pm 0$ & $87.5 \pm 5.0$ & 4.0 \\
\hline Aqueous phase & $535.0 \pm 21.2$ & $>1000 \pm 0$ & $>1.9$ \\
\hline \multicolumn{4}{|c|}{ 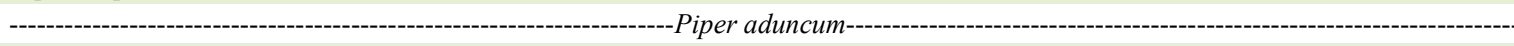 } \\
\hline Chloroform phase & $45.0 \pm 2.8$ & $39.0 \pm 22.6$ & 0.9 \\
\hline Aqueous phase & $585.0 \pm 7.0$ & $>1000 \pm 0$ & $>1.7$ \\
\hline \multicolumn{4}{|c|}{ 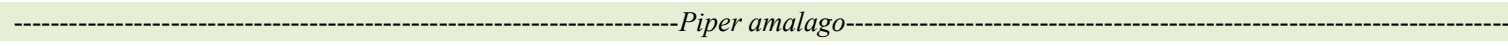 } \\
\hline Chloroform phase & $55.0 \pm 4.5$ & $275.0 \pm 49.9$ & 5.0 \\
\hline Aqueous phase & $18.0 \pm 11.1$ & $855.0 \pm 145.0$ & 47.5 \\
\hline
\end{tabular}

maximum concentration used $(1 \%)$ did not interfere with parasite growth.

RODRIGUES-SILVA et al. (2009) reported the in vitro activity of hydroalcoholic extract and fractions of Piper ovatum, against Leishmania amazonensis. A progressive increase in the antileishmanial effect was observed in the course of the fractionation. The dichloromethane and ethyl acetate fractions exhibited the best action against protozoa with $\mathrm{IC}_{50}$ values of $2,1 \mu \mathrm{g} \mathrm{mL} \mathrm{m}^{-1}$ for promastigotes and $24 \mu \mathrm{g} \mathrm{mL} \mathrm{m}^{-1}$ for amastigotes. These data corroborate the results of this study, since the same fractions showed higher antiprotozoal activity against $P$. serpens.

The action of the aqueous phase extracted from $P$. amalago was analyzed using scanning electron microscopy. The photomicrographs (Figure 5) reveal the differences in the morphology of promastigote cells treated with the extract when compared with the control (untreated cells). The control cells presented typical morphology of $P$. serpens, with elongated cell body, smooth cell

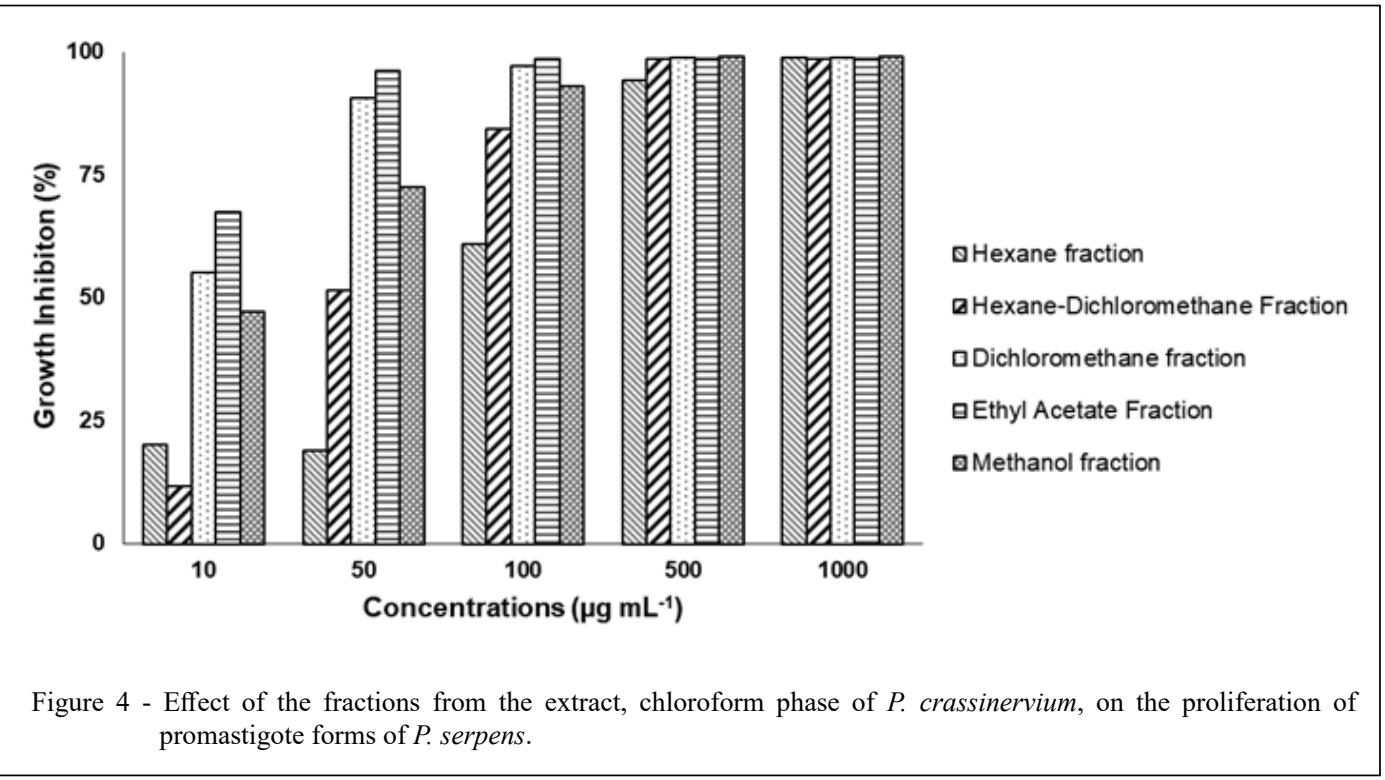

Ciência Rural, v.50, n.10, 2020. 

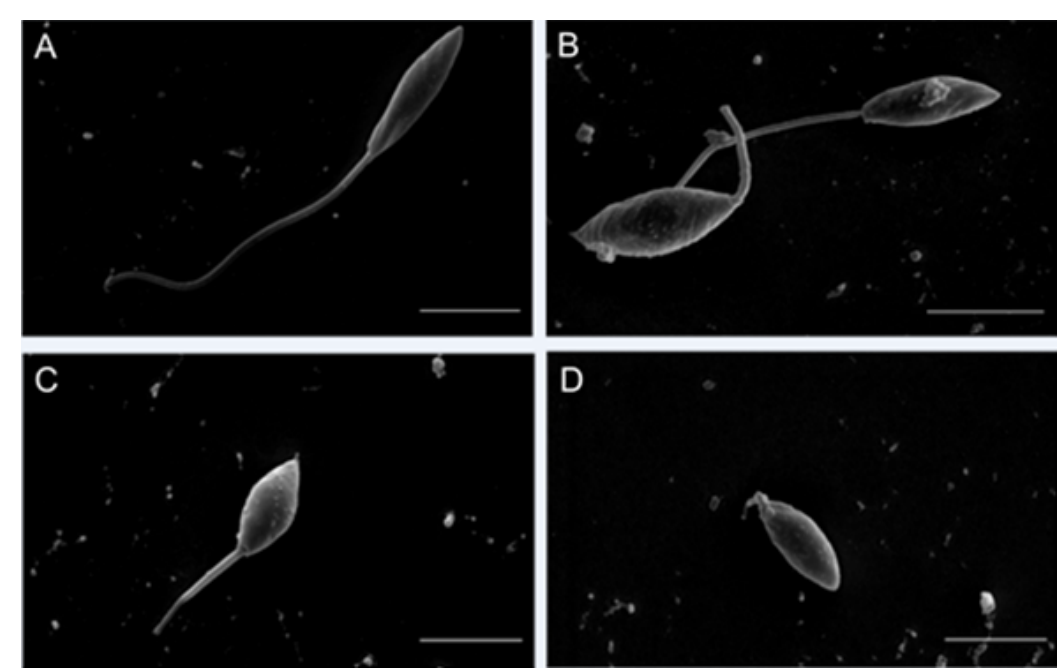

Figure 5 - Scanning electron microscopy of $P$. serpens promastigote cells, after $48 \mathrm{~h}$ treatment with the extract, aqueous phase of $P$. amalago: A) Control promastigote cells; $\mathrm{B}, \mathrm{C}$ and D) promastigote cells treated with $18 \mu \mathrm{g} \mathrm{mL}-1\left(\mathrm{IC}_{50}\right)$. Bar $=5 \mu \mathrm{m}$.

surface, and preserved terminal flagellum (Figure 5A). On the contrary, when promastigotes were treated with their respective $\mathrm{IC}_{50}$ values (Table 1), there were some changes in their structural integrity. The aqueous phase of $P$. amalago, induced changes in the cell membrane, detected by deformities on the cell surface (Figure $5 \mathrm{~B}$ ), with a reduction in volume and rounding of the cell body (Figure 5C). Besides, it caused shortening and/or loss of the flagellum (Figure 5D).

There are currently no control records for $P$. serpens, and significant research efforts have been made to achieve formulations that can be used in bioproducts for parasite management. According to SILVA et al. (2019), the essential oil of Varronia curassavica (Cordiaceae) has an antiprotozoal activity against $P$. serpens by causing changes in the permeability of the cytoplasmic membrane of promastigote cells, reaching up to $75 \%$ reduction in cellular proliferation of parasites exposed to the essential oil.

MEDINA et al. (2015) investigated the toxicity of alkaloids produced by tomato plants, called tomatine and tomatidine, in inhibiting the growth of $P$. serpens. Results indicated that the tomatine is capable of disrupting the structure of the plasma cell membrane, causing the death of the parasite. However, tomatidine only interferes with growth due to the inhibition of sterol synthesis. Similar results have been described by EVANGELISTA et al. (2018).

\section{CONCLUSION}

Ethanolic crude extracts and Piperaceae fractions were effective against $P$. serpens, mainly because they showed higher selectivity to parasites than to $\mathrm{LLCMK}_{2}$ mammalian cells. Our results showed through the inhibitory concentrations obtained after P. crassinervium fractionation, an improvement in the antiprotozoal activity of dichloromethane and ethyl acetate fractions. Moreover, the damage detected by scanning electron microscopy confirmed the effect of treatment with the crude extract of $P$. amalago, which was able to generate evident morphological changes in promastigote cells of $P$. serpens.

Later studies are essential to determine the inhibiton in pathways caused by the extracts since the evaluation carried out in this study points out that extracts of the different Piper species can be considered promising sources for the bio-guided isolation of new active compounds, indicating biotechnological potential in the development of chemical controls.

\section{ACKNOWLEDGEMENTS}

Coordenação de Aperfeiçoamento de Pessoal de Nível Superior (CAPES), Brasil - Finance code 001, for financial support.

Ciência Rural, v.50, n.10, 2020. 


\section{DECLARATION OF CONFLICT OF INTERESTS}

The authors declared no potential conflicts of interest with respect to the research, authorship, and/or publication of this article.

\section{AUTHORS' CONTRIBUTIONS}

All authors contributed equally for the conception and writing of the manuscript. All authors critically revised the manuscript and approved of the final version.

\section{REFERENCES}

ABREU FILHO, B. A. et al. Surface component characterization as taxonomic tools for Phytomonas spp identification. Parasitology Research, v.87, n.2, p.138-44, 2001. Available from: $<$ https://doi. org/10.1007/PL00008566>. Accessed: Jul. 20, 2019. doi: 10.1007/ pl00008566.

BAPELA, M. J. et al. Antileishmanial activity of selected South African plant species. South African Journal of Botany, v.108, p.342345, 2017. Available from: <https://doi.org/10.1016/j.sajb.2016.08.014>. Accessed: Jul. 20, 2019. doi: 10.1016/j.sajb.2016.08.014.

BERTOL, J. W. et al. Antiviral activity of fractions from leaves of Piper regnelli var. pallescens. Brazilian Journal of Pharmacognosy, v.22, n.6, p.1290-1294, 2012. Available from: $<$ https://doi.org/10.1590/S0102-695X2012005000110>. Accessed: Jul. 19, 2019. doi: 10.1590/S0102-695X2012005000110.

CARGNIN, S. T. et al. Anti-Trichomonas vaginalis activity of Hypericum polyanthemum extract obtained by supercritical fluid extraction and isolated compounds. Parasitology International, v.62, p.112-117, 2013. Available from: $<$ https://doi.org/10.1016/j. parint.2012.10.006>. Accessed: Aug. 01, 2019. doi: 10.1016/j. parint.2012.10.006.

CARRARA, V. S. et al. HPLC Analysis of Supercritical Carbon Dioxide and Compressed Propane Extracts from Piper amalago L. with Antileishmanial Activity. Molecules, v.17, p.15-33, 2012. Available from: <https://doi.org/10.3390/molecules17010015>. Accessed: Aug. 01, 2019. doi: 10.3390/molecules17010015.

CAMARGO, E. P. Phytomonas and other trypanosomatid parasites of plants and fruit. Advances in Parasitology, v.42, p.29-112, 1999. Available from: <https://doi.org/10.1016/S0065308X(08)60148-7>. Accessed: Aug. 01, 2019. doi: 10.1016/s0065$308 \times(08) 60148-7$.

COSTA, G. M. et al. Antimicrobial effects of Piper hispidum extract, fractions and chalcones against Candida albicans and Staphylococcus aureus. Journal de Mycologie Médicale, v.612, p.10, 2016. Available from: <https://doi.org/10.1016/j. mycmed.2016.03.002>. Accessed: Aug. 02, 2019. doi: 10.1016/j. mycmed.2016.03.002.

DA SILVA, R. V.et al. Oral exposure to Phytomonas serpens attenuates Thrombocytopenia and Leukopenia during acute infection with Trypanosoma cruzi. PLoS ONE, v.8, n.7, p.e68299, 2013. Available from: <https://doi.org/10.1371/journal. pone.0068299>. Accessed: Aug. 02, 2019. doi: 10.1371/journal. pone. 0068299 .
EVANGELISTA, A. F. et al. Behavior of $\alpha$-tomatine and tomatidine against several genera of trypanosomatids from insects and plants and Trypanosoma cruzi. Acta Scientiarum Biological Sciences, v.40, p.e41853, 2018. Available from: <https://doi.org/10.4025/ actascibiolsci.v40i1.41853>. Accessed: Aug. 02, 2019. doi: 10.4025/actascibiolsci.v40i1.41853.

FERNANDEZ, C. M. M. et al. Anti-Mycobacterium tuberculosis activity of dichloromethane extract of Piper corcovadensis (Miq.) C. DC. roots and isolated compounds. Industrial Crops \& Products, v.131, p.341-347, 2019. Available from: <https://doi. org/10.1016/j.indcrop.2019.01.064>. Accessed: Aug. 02, 2019. doi: 10.1016/j.indcrop.2019.01.064.

FROLOV, A. O. et al. Development of Phytomonas lipae sp. n. (Kinetoplastea: Trypanosomatidae) in the true bug Coreus marginatus (Heteroptera: Coreidae) and insights into the evolution of life cycles in the genus Phytomonas. PLoS ONE, v.14, n.4, p.e0214484, 2019. Available from: <https://doi.org/10.1371/journal.pone.0214484>. Accessed: Aug. 02, 2019. doi: 10.1371/journal.pone.0214484.

GARCIA, F. P. et al. Eupomatenoid-5 Isolated from Leaves of Piper regnellii Induces Apoptosis in Leishmania amazonensis. Evidence-Based Complementary and Alternative Medicine, 2013. Available from: <https://doi.org/10.1155/2013/940531>. Accessed: Aug. 02, 2019. doi: 10.1155/2013/940531.

IENNE, S. et al. Auxin production by the plant trypanosomatid Phytomonas serpens and auxin homoeostasis in infected tomato fruits. Parasitology, v.141, p.1299-1310, 2014. Available from: $<$ https://doi.org/10.1017/S0031182014000547>. Accessed: Aug. 02, 2019. doi: 10.1017/S0031182014000547.

JANKEVICIUS, J. V. et al. Life cycle and culturing of Phytomonas serpens (gibbs), a trypanosomatid parasite of tomatoes. Journal of Protozoology, v.36, p.265-271, 1989. Available from: <https:// doi.org/10.1111/j.1550-7408.1989.tb05361.x>. Accessed: Aug. 02, 2019. doi: 10.1111/j.1550-7408.1989.tb05361.x.

JASKOWSKA, E. et al. Phytomonas: trypanosomatids adapted to plant environments. PLoS Pathogens, v.11, p.e1004484, 2015. Available from: <https://doi.org/10.1371/journal.ppat.1004484>. Accessed: Aug. 02, 2019. doi: 10.1371/journal.ppat.1004484.

KAUFER, A. et al. The evolution of trypanosomatid taxonomy. Parasites \& Vectors, v.10. p.287, 2017. Available from: <https:// doi.org/10.1186/s13071-017-2204-7>. Accessed: Aug. 02, 2019. doi: 10.1186/s13071-017-2204-7.

KUMAR, Y. et al. AromaDb: A database of medicinal and aromatic plant's aroma molecules with phytochemistry and therapeutic potentials. Frontiers in Plant Science, v.9, p.1081, 2018. Available from: <https://doi.org/10.3389/fpls.2018.01081>. Accessed: Aug. 02, 2019. doi: 10.3389/fpls.2018.01081.

LAGO, J. H. G.; KATO, M. J. 3 $\alpha, 4 \alpha$-Epoxy-2-piperidone, a new minor derivative from leaves of Piper crassinervium Kunth (Piperaceae). Natural Product Research, v.21, p.910-914, 2007. Available from: <https://doi.org/10.1080/14786410601130711>. Accessed: Aug. 02, 2019. doi: 10.1080/14786410601130711.

LONGATO, G. B. et al. In vitro and in vivo anticancer activity of extracts, fractions and eupomatenoid-5 obtained from Piper regnelli leaves. Planta Medica, v.77, p.1482-1488, 2011. Available from: $<$ https://doi.org/10.1055/s-0030-1270889>. Accessed: Aug. 02, 2019. doi: 10.1055/s-0030-1270889. 
LOPES, A. A. et al. In vitro activity of compounds isolated from Piper crassinervium against Trypanosoma cruzi. Natural Product Research, v.22, n.12, p.1040-1046, 2008. Available from: <https:// doi.org/10.1080/14786410802243271>. Accessed: Aug. 02, 2019. doi: $10.1080 / 14786410802243271$.

MASLOV, D. A. et al. Recent advances in trypanosomatid research: genome organization, expression, metabolism, taxonomy and evolution. Parasitology, v.146, p.1-27, 2018. Available from: $<$ https://doi.org/10.1017/S0031182018000951>. Accessed: Aug. 02, 2019. doi: 10.1017/S0031182018000951.

MEDINA, J. M. et al. Mechanisms of growth inhibition of Phytomonas serpens by the alkaloids tomatine and tomatidine. Memórias Instituto Oswaldo Cruz, v.110, n.1, p.48-55, 2015. Available from: <https://doi.org/10.1590/0074-02760140097>. Accessed: Aug. 02, 2019. doi: 10.1590/0074-02760140097.

OLIVEIRA, S. S. C. et al. Susceptibility of Phytomonas serpens to calpain inhibitors in vitro: interference on the proliferation, ultrastructure, cysteine peptidase expression and interaction with the invertebrate host. Memórias Instituto Oswaldo Cruz, v.112, n.1, p.31-43, 2017. Available from: <https://doi.org/10.1590/007402760160270>. Accessed: Aug. 02, 2019. doi: 10.1590/007402760160270 .

PASCOLI, I. C. et al. Piperaceae extracts for controlling Alicyclobacillus acidoterrestris growth in commercial orange juice. Industrial Crops and Products, v.116, p.224-230, 2018. Available from: <https://doi.org/10.1016/j.indcrop.2018.02.073>. Accessed: Aug. 02, 2019. doi: 10.1016/j.indcrop.2018.02.073.

PEREIRA, A. O. et al. Chemical composition, antimicrobial and antimycobacterial activities of Aristolochia triangularis Cham. from Brazil. Industrial Crops Products, v.121, p.461-467, 2018. Available from: <https://doi.org/10.1016/j.indcrop.2018.05.052>. Accessed: Aug. 02, 2019. doi: 10.1016/j.indcrop.2018.05.052.
PORCEL, B. M. et al. The streamlined genome of Phytomonas spp. relative to human pathogenic kinetoplastids reveals a parasite tailored for plants. PLoS Genetics, v.10, n.2, p.e100400, 2014. Available from: <https://doi.org/10.1371/journal.pgen.1004007>. Accessed: Aug. 02, 2019. doi: 10.1371/journal.pgen.1004007.

PRANDO, T. et al. Amides from Piper as a diuretic: Behind the ethnopharmacological uses of Piper glabratum Kunth. Evidence-Based Complementary and Alternative Medicine, 2014. Available from: <https://doi.org/10.1155/2014/615109>. Accessed: Aug. 02, 2019. doi: 10.1155/2014/615109.

RODRIGUES-SILVA, D. et al. In vitro antileishmanial activity of hydroalcoholic extract, fractions, and compounds isolated from leaves of Piper ovatum Vahl against Leishmania amazonensis. Acta Protozoologica, v.48, p.73-81, 2009. Available from: $<$ https://doi.org/10.1055/s-0029-1234508>. Accessed: Aug. 02, 2019. doi: $10.1055 / \mathrm{s}-0029-1234508$.

SILVA, K. P. et al. Using Varronia curassavica (Cordiaceae) essential oil for the biocontrol of Phytomonas serpens. Industrial Crops and Products, v.139, p.111523, 2019. Available from: $<$ https://doi.org/10.1016/j.indcrop.2019.111523>. Accessed: Aug. 02, 2019. doi: 10.1016/j.indcrop.2019.111523.

SKEHAN, P. et al. New colorimetric cytotoxicity assay for anticancer-drug screening. Journal National Cancer Institute, v.82, n.13, p.1107-12. 1990. Available from: <https://doi. org/10.1093/jnci/82.13.1107>. Accessed: Aug. 02, 2019. doi: 10.1093/jnci/82.13.1107.

VILLAMIZAR, L. H, et al. Linalool, a Piper aduncum essential oil component, has selective activity against Trypanosoma cruzi trypomastigote forms at $4{ }^{\circ} \mathrm{C}$. Memórias Instituto Oswaldo Cruz, v.112, n.2, p.131-139, 2017. Available from: $<$ https://doi. org/10.1590/0074-02760160361>. Accessed: Aug. 02, 2019. doi: 10.1590/0074-02760160361. 